УДК 780.616.432:78.03(510)'06

DOI 10.34064/khnum2-2115

\title{
Чжан Гуанцзянь
}

ORCID 0000-0001-5387-6469

Харківський національний університет мистецтв імені І. П. Котляревського, 61003, майдан Конституиії 11/13, м. Харків, Украӥна

\section{Проблеми інтерпретації фортепіанних творів Чжан Чжао (на прикладі фантазії «Піхуан»)}

АНОТАЦІЯ Чжан Гуанцзянь. Проблеми інтерпретації фортепіанних творів Чжан Чжао (на прикладі фантазії «Піхуан»). - Творчість відомого сучасного композитора Чжан Чжао привертала увагу ряду китайських дослідників, однак його фортепіанні твори не розглядалися в аспекті виконавської специфіки. Мета статті - виявити універсальний механізм 
інтерпретації фортепіанних композицій Чжан Чжао на прикладі його фантазії «Піхуан», основні виконавські завдання твору та шляхи їхньої реалізації. Цей твір, де втілено національні риси пекінської опери «піхуан», був удостоєний почесної нагороди національного композиторського конкурсу (2007) за високі художні якості та глибоку змістовність. Досліджується, яким чином Чжан Чжао використовує музичні елементи китайської оперної традиції для вибудовування певної драматургії твору, як втілюється на фортепіано звукова специфіка тембральних барв голосу, прийомів вокального звуковидобування та декламації, образів традиційних китайських інструментів. Виявляється роль першого виконавця твору - відомого піаніста Лі Юнді - у популяризації творів Чжан Чжао в Китаї та за його межами. Доводиться методологічна важливість розгляду виконавського аспекту реалізації даної музики. Підкреслюється, що подібний аналіз створює широке поле для творчого пошуку в сфері інтерпретування музики китайських авторів, враховує сучасні вимоги, що сприяють розвитку самостійності та ініціативності у молодих піаністів. К Ключові слова: Чжан Чжао, китайська фортепіанна музика, фантазія «Піхуан», виконавська інтерпретація, піаністичні завдання, майстерність піаніста-виконавия, Лі Юнді.

\section{АННОТАЦИЯ — Чжан Гуанцзянь. Проблемы интерпретации} фортепианных сочинений Чжан Чжао (на примере фантазии «Пихуан»).

- Творчество известного современного композитора Чжан Чжао привлекало внимание ряда китайских исследователей, однако его фортепианные произведения не рассматривались в аспекте исполнительской специфики. Цель статьи - выявить универсальный механизм интерпретации фортепианных композиций Чжан Чжао на примере его фантазии «Пихуан», основные исполнительские задачи произведения и пути их реализации. Это сочинение, где воплощены национальные черты пекинской оперы «пихуан», было удостоено почётной награды национального композиторского конкурса (2007) за высокие художественные качества и глубокую содержательность. Исследуется, каким образом Чжан Чжао использует музыкальные элементы китайской оперной традиции для выстраивания драматургии произведения, как воплощается на фортепиано звуковая специфика тембральных красок голоса, приёмов вокального звукоизвлечения и декламации, образов традиционных китайских инструментов. Выявляется роль первого исполнителя 
произведения - известного пианиста Ли Юнди - в популяризации произведений Чжан Чжао в Китае и за его пределами. Доказывается методологическая важность рассмотрения исполнительского аспекта реализации данной музыки. Подчёркивается, что подобный анализ создаёт широкое поле для творческого поиска в сфере интерпретации музыки китайских авторов, учитывает современные требования, способствующие развитию самостоятельности и инициативности у молодых пианистов. - Ключевые слова: Чжан Чжао, китайская фортепианная музыка, Фантазия «Пихуан», исполнительская интерпретачия, пианистические задачи, мастерство пианиста-исполнителя, Ли Юнди.

\section{ABSTPACT - Zhang Guangjian. Problems of interpretation of the piano compositions by Zhang Zhao (on the example of the Fantasy "Pihuang").}

- Background. The article is devoted to the piano work of the famous Chinese composer Zhang Zhao. The focus is on the "Pihuang" Fantasy, which embodies the national characteristics of Peking opera. This work won an honorary award at the 2007 Chinese composition competition for high artistic qualities and deep content. The article examines, how the composer uses the musical elements of the Chinese opera tradition to create a certain drama of the work, how the sound specificity of the timbre colors of the voice, the techniques of vocal sound production and recitation, the image of Chinese instruments is embodied on the piano. The role of the first performer of the work - the famous pianist Li Yundi - is revealed to popularize the works of Zhang Zhao in China and around the world. The importance of considering the performing aspect of the realization of this music is proved. It is emphasized, that such an analysis creates a wide field for creative research in the interpretation of the music by Chinese authors, takes into account modern requirements that contribute to the development of independence and initiative among young pianists.

Objectives. The purpose of the article is to identify the universal mechanism for interpreting the piano compositions of Zhang Zhao by the example of his Fantasy "Pihuang". For the disclosing of the research theme the complex methodological approach, combining the principle of musical-theoretical, musical-historical and performing analysis is taken.

Results. The composer also embodied the centuries-old traditions of Chinese instrumental folk art, its timbre specificity and unique rhythm in the piano sound 
of the Fantasy "Pihuang". An important point is the formal and dramaturgical organization of this composition. Zhang Zhao organically combines the traditional mosaic structure of the Beijing opera with the Western genre of opera transcription, which allowed to give the whole musical composition "elasticity" within the framework of a fixed large form. This work attracts not only with the beauty of its melodies, the richness and originality of a harmonic language, the perfection of a form, various requirements for a performer, but also because all these features of his music are inextricably linked with the disclosure of the philosophical depth of content and eternal vital themes in it. A performer should be ready for frequent changes in images and moods, since the work of Zhang Zhao is romantic, rich in figurative and emotional content. From this point of view, one need to imagine different plot scenes and relate them to the sections of the music. The various characteristics of the sections will help a pianist to some extent decide, which timbres, tempo and mood are most appropriate. Throughout the performance, a pianist must be in the determined "role". The piece opens by the loose improvisatory introduction, Rubato. The pianist must listen in advance to the Beijing opera in order to imagine how this music should sound, to understand and feel the free movement of its rhythmic organization (sang-bang). To achieve expressiveness in melodies, preeminently, one needs to have a flowing, singing sound. Sound quality is determined by the style and nature of the work, where each of the episodes and even a separate voice in polyphony require special coloring and special sound production.

The task of the performer is to show as more clearly the features that are essential for various types of the texture presentation: in the same material one can emphasize the melodic beginning or the character of the chord movement, give preference to the bass part or soprano echo; finally, highlighting a certain chord sound, one can strengthen the latter's attraction to a particular functional sphere. It is well known, that a performer can, without deviating from the pitch line given by a composer, but actively using the means of dynamics, articulation, agogy, create an individual version of the melodic pattern with its own logical emphasizes, its own types of breath and plasticity. It is obvious, that the study of the laws expressing the substantial characteristics of the texture is of practical importance for the performer, since the texture is directly related to the problem of figurative-sound versatility of performance - one of the most acute for musical interpretation. Therefore, a performer's attention to a significant extent should 
be focused on which figurative-semantic characteristics are concentrated in each texture layer, what of these characteristics are dominant and what constitute the psychological complement of the image or act as an opposing force.

Conclusions. "Pihuang" attracts the attention of performers with the uplifting and joy of vitality, original, artistic language, specificity of rhythm, and improvisation. This work reflects the highest achievements of the Chinese pianistic school, the importance of which has long crossed national boundaries, occupying one of the honorable places in the education of young pianistsperformers. The study of the performing interpretation of the piano works by Zhang Zhao, the identification of the relationship between expressive techniques and the peculiarities of the author's style has many-sided significance. Based on the analysis of the interpretation of the Piano Fantasy "Pihuang" by the outstanding Chinese pianist Yundi Li, as well as checking the conclusions of theoretical analysis with the practice of concert performances, we establish certain connections in Zhang Zhao's piano work, which can be traced as stable signs of his style. It should be noted that different performers can reveal a significantly different understanding of the same work and sometimes we have to talk about the difference in the very content of the sounding work. Auditory impressions from listening to Beijing opera, the sound of Chinese folk instruments should be the basis for the realization of the objective properties of the piano texture, reproduction on the piano laid in the musical notation features of rhythm, dynamics, agogics, timbres etc. This not only clarifies the understanding of the composer's style, but also the specifics of all Chinese performing arts. - Key words: Zhang Zhao, Chinese piano music, Fantasy "Pihuang”, performing interpretation, pianistic complexities, pianistic mastery, Li Yundi.

Постановка проблеми. Сьогодні творчість сучасного китайського композитора Чжан Чжао (нар. 1964) стає відомою не тільки в Китаї, але і в інших країнах світу. Більшість його фортепіанних творів - концерт «Рапсодія Айлао», фантазія «Піхуан», «Китайська фортепіанна мрія», «В найвіддаленішому місці», «Три пісні південних передгір'їв», «Китайські мелодії» та інші - характеризується розмаїтою звуковою палітрою, яскравою колористикою, найскладнішими 
піаністичними прийомами. Однак цей багатий репертуар ще не розглядався в музикознавстві в аспекті виконавського аналізу, проблеми осмислення його піаністичної реалізації на даний час не досліджені. Рішення такого роду завдань відкриває шляхи до розуміння змісту цих творів, допомагає виконавцю створити необхідні звукові уявлення для роботи над ними. Подібний підхід до дослідження «формальних відносин, функцій елементів і їх взаємодій спрямований на розуміння виконавцем музичного тексту як мови і як твору мистецтва, як поетичної мови і як образної структури i, в кінцевому підсумку, як художнього музичного феномена, побудованого за ясними і зрозумілими законами» (Дятлов, 2013: 805). Отже, видається за необхідне здійснення виконавського аналізу фортепіанних творів Чжан Чжао, що створить широке поле для творчого пошуку в сфері інтерпретування його музики з урахуванням сучасних вимог, які пред'являються до самостійності та ініціативності молодих піаністів.

Аналіз останніх публікацій по темі дослідження. Незважаючи на те, що творчість Чжан Чжао привернула увагу ряду китайських дослідників, серед яких - Дуань Вей (2016), Йі Хонг (2015), Цзін Цзінлан (2006), Ці Цзін (2015), Чжан Хунвей (2016), Ні Ін (2015) - фортепіанні твори композитора не розглядалися в аспекті виконавських завдань і проблем їх реалізації.

Мета статті - виявлення універсального механізму інтерпретації фортепіанних композицій Чжан Чжао на прикладі його фантазії “Піхуан”, основних виконавських проблем твору та шляхів їх реалізації. Для розкриття теми дослідження використано комплексний методологічний підхід, що поєднує в собі принципи музично-теоретичного, музично-історичного та виконавського аналізу.

Виклад основного матеріалу дослідження. Фантазія «Піхуан», що стала переможницею на Національному конкурсі композиції (2007), є одним з найяскравіших і відомих творів Чжан Чжао. Цей твір має високі художні вартості та глибокий зміст. Композитор не просто відобразив в ньому елементи китайської оперної традиції, але вибудував свій фортепіанний твір відповідно до театральних особливостей опери «піхуан». Чжан Чжао органічно синтезує дані риси із західним жанром фортепіанної оперної транскрипції, що дозволило надати всій 
музичній структурі «пружність» в рамках фіксованої великої форми. Таким чином, в фортепіанному звучанні втілилися стародавні традиції китайської театрально-музичної творчості, темброва специфіка і унікальна ритміка вокально-сценічної музики.

Драматургія твору відповідає традиційній мозаїчній структурі пекінської опери, в ній використовуються відомі типи мелодій - cini (весела, жива) і ерхуан (сумна, драматична). Фантазію відкриває розгорнутий вступ Rubato, що передує основній частині композиції. Цей розділ можна зіставити з оперною увертюрою; він звучить до основної теми-мелодії і сприяє загальному налаштуванню як виконавця, так і слухачів. Піаніст повинен обов’язково послухати пекінську оперу, щоб отримати уявлення про те, як звучать китайські інструменти, зрозуміти і відчути особливості ритмічної організації сань-бань. Це поняття можна визначити як невпорядкованість (сань) ритму, метру, темпу, темпову свободу. Це дуже важливо для усвідомлення природи китайської музики при іï виконанні. Так, в темі вступу піаніст має втілити звукові особливості барабанів, удари яких відкривають вільний перебіг музики. Застосування агогічних нюансів accelerando i ritardando дозволяс гнучко трактувати звучання барабанів, тоді як в європейській музиці подібні інструменти частіше асоціюються 3 остинатним ритмом. Часова організація в традиціях сань-бань, подібна до європейського поняття rubato, заявленого композитором на початку твору, дає відчуття імпровізаційного вступу. Виконуючи початкові удари барабана у вільному русі, виконавець то прискорює, то сповільнює їх швидкість.

Фортепіанна фактура обумовлена специфікою гри на китайських інструментах. Так, у вступі, досягаючи звуконаслідувального ефекту ударів барабанів, важливо виконувати основні звуки, використовуючи сильний перший палець. Традиція виконання на циинь втілюється на фортепіано в такий спосіб: першим пальцем виконуються найсильніші звуки, які підтримуються арпеджійованими співзвуччями. Такий виконавський прийом називається цуа, що означає акцентування звуку, виконуваного першим пальцем. При цьому звук має велику тривалість. Виконання швидких пентатонних гам вимагає особливої технічної підготовки виконавця. Піаніст постійно повинен стежити за 
розташуванням своїх рук і пальців, оскільки фігурації досить швидко змінюються, чергуючи білі та чорні клавіші фортепіано. Цей прийом незвичний західним виконавцям, тому потрібен деякий час, щоб вони звикли і адаптувалися до подібного типу позиційного розташування послідовностей.

Andante Pacatamente містить пряме відсилання до матеріалів пекінської опери. Воно відкривається співучим дуетом, який супроводжується «застиглими» на тривалому проміжку часу квінтами і квартами. Композитор використовує «властивий імпресіонізму прийом довгого “милування” однією фарбою» (Чень Жуньсюань, 2014: 73), відлуння, зіставлення. Дані звукозображальні ефекти виконавець зможе передати, якщо буде знайомий з багатими тембровими можливостями та ігровими прийомами китайського інструмента niбu. Зіставлення основних тем завжди вимагає, щоб піаніст вів одночасно кілька різнотембрових звукових ліній. Застосування контрастної поліфонії вимагає не тільки слухового контролю звуковидобування і педалізації, але і знайомства піаніста з темами пекінської опери, а також того, щоб він приділяв пильну увагу розпізнаванню і озвученню різних мелодичних ліній. Тому дуже важливі точність і зосередженість, а також момент слухового передслухання, завбачання, яке забезпечить чутливість дотику до клавіш і уважне використання педалі. Через розбіжності ритмічного малюнка в різних голосах часто виникають труднощі у виконанні.

Allegretto Innocente вносить невелике пожвавлення, про що свідчать зміна штриха, посилення емоційного тонусу. Примхливо кучерява мелодія немов «підстрибує» на тлі остинатної лінії на staccato, передає відчуття грайливою безтурботності. Дослідник Йі Хонг бачить в даному епізоді картину «дитинства композитора, проведеного в іграх і витівках в мальовничому місці Юньнані, на тлі красот озера Дзянчі. Композитор змушує задуматися над істинним сенсом життя, коли небо було безхмарним і був час для чистої і красивої любові» (Йі Хонг, 2015: 117). Ми спостерігаємо в цьому розділі ясно виражену національну основу - використання характерних інтонаційних оборотів, остинатну лінію в нижньому голосі, що нагадує звучання народних китайських інструментів, своєрідне застосування орнамен- 
тальних прикрас. Про це ж свідчать простота викладу і квадратність структури, ритми, моторика і технічні прийоми. Однак ці, на перший погляд, прості форми викладу ставлять відповідальні завдання для піаніста, який прагне осягнути глибину художнього змісту цього твору.

У наступних розділах - Allegro zeffiroso і буквально відразу наступаючому Vivace Spirito, головним чином, відображена типова героїчна романтика: персонаж музичного твору, перемагаючи знегоди, долає нелегкий життєвий шлях. Фактура переважно передбачає використання пальцьової техніки. Оскільки мелодичні фігурації побудовані на тривалому безперервному русі, на перший план, безумовно, виходить технічний рівень виконавця, його можливості тривалий час розгортати музичні побудови. Тільки при правильній і зручній аплікатурі можна домогтися рівності звучання, а також контрасту між ріaпо i forte в пасажах. Особливої уваги вимагає вибір аплікатури в обох руках, принципи побудови якої не повинні входити в протиріччя між собою. Рухові якості піаністичного апарату в заняттях виконавця мають одне 3 першорядних значень. Швидкість і вправність, точність і здатність до тривалої фізичної напруги - все це якості, необхідні кожному виконавцю для інтерпретації творів китайських композиторів.

Взаємини між художньо-виразними уявленнями і технічними засобами дають можливість осягнути ті складні зв'язки, які виникають між свідомістю і аналітичною діяльністю та моторикою. Не заперечуючи залежності вибору технічних прийомів від художнього образу, існує зв'язок іншого типу: творчий задум народжується технічними прийомами. Помічено, що не тільки моторика є продуктом свідомої діяльності, а й сам художній образ багато в чому продиктований специфікою вибору технічних засобів. Таким чином, техніка виявляє тісний і нерозривний зв'язок між внутрішнім чуттям і сприйняттям. Моторика є сполучною ланкою, яка з'єднує художній образ з його реальним втіленням, i, в той же час, зближує представлений образ із реально сприйнятим образом. Тому надзвичайно важливим вбачається гармонійний розвиток звукових уявлень і фантазії піаніста, збагачення його технічного потенціалу. Композитор підходить до можливостей виконавця творчо, не розглядаючи зручність виконання і «виграшність» твору як самоціль, він вважає, що тільки при постійному 
контролі думки над рухом музичного образу можна підпорядкувати техніку реальним художнім завданням (Чжан Гуанцзянь, 2019).

У ліричному розділі фантазіі - Largo a capriccioso - Чжан Чжао розкриває колористичні і поліфонічні можливості фортепіано. Перед очима немов постають пейзажні замальовки - можливо, навіяні спогадами автора про місто Куньмін - сучасну столицю провінції Юньнань на півдні Китаю. Композитор любить своє рідне місто і прославляє його історію та культуру. Для досягнення виразності мелодій цього розділу потрібно, в першу чергу, оволодіти співучим плинним звуком. Якість звуку визначається стилем твору, де кожен епізод і навіть окремий голос в поліфонії вимагають особливого забарвлення і звуковидобування, конкретно поставленим художнім завданням. Важлива роль належить рельєфному фразуванню і пластиці гри, без якої не може бути й мови про натхненну передачу задуму композитора.

Крім цього, музика часто передбачає неоднозначні рішення: в одному і тому ж матеріалі можна підкреслити мелодичне начало або характерність акордового руху, віддати перевагу басовій партії або сопрановим підголоскам, нарешті, виділивши певний звук акорду, можна підсилити тяжіння останнього до тієї чи іншої функціональної сфери. Загальновідомо, що виконавець може, не відхиляючись від даної звуковисотної лінії, але активно використовуючи засоби динаміки, артикуляції, агогіки, створити індивідуальний варіант мелодичного малюнка зі своїми логічними наголосами, своєю пластикою і диханням. Більш того, за допомогою тих же засобів можна досягти відчуття підвищення або зниження висоти звуку в умовах темперованого строю фортепіано. Проблема образно-звукової багатоплановості виконання - одна з найважливіших в області музичної інтерпретації. Тому увага виконавця в значній мірі має бути зосереджена на тому, які образно-смислові характеристики сконцентровані в кожному фактурному шарі: які 3 них виявляються домінуючими, а які становлять психологічне доповнення образу або виступають в ролі «протиборчої» сили.

Важливим аспектом виконавської реалізації музики є педалізація, оскільки витонченість відтінків не піддається точній нотній фіксації. Ще складніше проставляти педалізацію там, де вона виконує колористичні функції. В творі Чжан Чжао не обійтися без педалі: вона 
призначена для тембрового збагачення, плавного загасання звуку перед паузами, накопичення мощі при підходах до динамічної кульмінаціiі, створення глибини гармонічного фону і додання поліфонічного, для надання звуку рельєфності, пом'якшення удару, допомоги пальцям в скрутних аплікатурних випадках і т. ін.

Allegro vivace виконує функцію розробки, приводячи музичне дійство до Vivace angoscioso, де виконавець знову зустрічається з унікальним феноменом часової організації китайської музики сань-бань. Відчуття ритмічної свободи і гнучкості виконання представляється дуже важливим, оскільки подібне володіння часом визначає такі образні характеристики, як імпровізаційність, миттєвість, спонтанність. Особливу виразність даним епізодом надає індивідуальне тлумачення ритмічних структур, звуковисотної інтонації (для інструментів з нефіксованим ладом і голосу це - потужний засіб впливу на слухача), артикуляції, темпових співвідношень та ін. Природно, визначаючи параметри того чи іншого засобу, виконавець повинен узгоджуватися 3 пануючими тенденціями їх взаємовідносин, не порушуючи випадковими, необгрунтованими рішеннями логіку цілого.

Вільна ритміка і колористичні звукові прийоми надають цьому розділу яскраве національне забарвлення. Агогіка і хвилеподібна динаміка дозволяють досягти специфічних тембрових фарб. Такими засобами досягається ефект звучання циитри чжен, коли два (або більше) тони звучать синхронно, якщо музикант защипує дві або більше струн одночасно. Відкривається і дивовижне багатство метроритмічних знахідок, які наділяють музику примхливою ритмічною пластикою. Інтервали і гармонії, що тягнуться на педалі, заповнюються ніжними струмливими пасажами. Виразність метроритму йде від своєрідного переломлення ритмоформул народної інструментальної музики, а виразність мелодики утворюється під впливом інтонаційної специфіки національної музичної мови. Фактура, розростаючись, ускладнюється і поступово охоплює весь діапазон фортепіано, що призводить до ефектного закінчення віртуозними пасажами, martellato i glissando. У процесі збільшення звукової маси необхідно стежити за якістю дотику до клавіш і педалізацією, у підході до кульмінації потрібно неухильно нарощувати динаміку. Безсумнівно, виконання такого му- 
зичного матеріалу вимагає від піаніста технічної майстерності, масштабності мислення.

Два акцентованих акорди, що імітують гучні удари гонгів і тарілок, використовуваних в пекінській опері, призводять до кульмінаційного Presto Sdegnoso. Виконавець повинен трактувати контрапункт як прояв ансамблевості і мислити оркестровими тембрами: необхідно прагнути до відтворення в фортепіанній фактури звучання кількох різних груп китайського оркестру. Найважливішу роль відіграють струнні інструменти, оскільки композитор надав велике значення руховим прийомам, штрихам, що імітують звуковидобування на арху, niбi, гуцинь. Екзотичність звучання, специфіка метроритму, примхливість мелодій, оригінальність музичної мови можуть спровокувати піаніста до надмірно темпераментного виконання. I, хоча фантазія не має бути скутою, а емоціям необхідно знаходити повнокровний вихід, все ж почуття міри не повинно відмовляти піаністові.

Напруження емоцій демонструє заключний розділ Andante Brillante, де звукові барви увібрали багатство фортепіанних тембрів, і який далі переростає в справжнє акордове tutti, наповнене особливою дзвінкістю, ударністю і, водночас, співучістю. Виконавцю необхідно виявити здатність переключатися від імпровізаційного висловлювання до відчуття злагодженості оркестрового викладу, повнокровного, сповненого пафосу, звучання. Важливе значення мають цезури, які розділяють такі масштабні побудови. Момент дихання завжди пов'язаний з мелодичною рельєфністю, об'ємністю звучання і змістовністю інтонацій, які проспівуються або вимовляються. Внутрішнє дихання надає рельєф, об'єм мелодичним лініям, окремим моментам виразного фразування і життєвість твору в цілому.

Виконавцю рекомендується подумати про акордову фактуру, що дуже часто є багатоярусним нашаруванням, яке можна зіставити 3 хором. Велику роль в фортепіанному викладі грає пісенне начало; як правило, вся фактура є мелодичною. Поліфонічні переплетення різних голосів дають можливість роялю співати багатоголосно. Хвилеподібна динаміка і органний пункт в нижньому регістрі створюють ефект звукового простору, допомагають відчути піднесений тон музичного висловлювання. 
Роль творчої співучасті виконавця у вибудовуванні художнього образу в сучасній музиці особливо зростає. Звукотворча воля піаніста сприяє можливості індивідуального вкладу виконавця як співавтора композитора в процесі реалізації музичного змісту твору. Чжан Чжао знайшов в особі піаніста-віртуоза Юнді Лі свого однодумця. Співпраця композитора і виконавця почалася в 2011 р. (Чжан Гуанцзянь, 2019). 3 того часу піаніст став не просто першим виконавцем творів Чжан Чжао, а й їх пропагандистом. Одним $з$ таких творів, безсумнівно, є «Піхуан».

Виконуючи фортепіанну фантазію, Юнді Лі трактує іï як масштабну театрально-драматичну дію, відкриваючи в кожному розділі нову грань образності. Ритмічна імпульсивність і свобода проявляються в його грі як гнучкий музичний рух. Піаніст опукло підкреслює якісні властивості артикуляції мелодії, а також надає фортепіанній ритміці ту своєрідну нерівномірну розчленованість, при якій довгі лінії створюються як би постійним припливом коротких мотивів, їх несиметричною в'яззю, яка створює єдине ціле. Музична фраза має у виконавця свою внутрішню пульсацію, що відбиває імпровізаційну манеру вислову, фактично підпорядковану rubato, яке можна зафіксувати приблизно так: стриманий початок фрази, розбіг, уповільнення і підкреслено уривчасте іiі закінчення. Піаніст блискуче диференціює тембри і регістри фактурних шарів, гранично оголюючи внутрішню конструкцію тканини, вводить особливі прийоми звуковидобування, пов’язані $з$ динамізуючою та колористичною педалізацією.

Гонконгський музикознавець Лоуренс Лок під час інтерв'ю запитав Юнді Лі: «Вивчаючи новий твір, чи слухаєте Ви записи, чи порівнюєте Ви різні інтерпретації?». Піаніст відповів: «С різні способи вивчити новий твір. Слухання компакт-дисків - легкий шлях, але він може привести до наслідування. У той же час, слухання інших інтерпретацій може принести нове розуміння, тому, слухаючи, я обмірковую, спостерігаю і думаю, а це не може бути погано. Я люблю гарних виконавців. Кожен з них має власний стиль - їх важко порівнювати. Я завжди любив Артура Рубінштейна, Крістіана Циммермана та Мауріціо Полліні» (Lock, 2003: 6). 
Висновки. Фантазія «Піхуан» Чжан Чжао приваблює не тільки красою своїх мелодій, багатством і оригінальністю гармонічної мови, досконалістю форми, різноманітними вимогами, що пред’являються до виконавця, а й тим, що інтерпретування його музики пов'язане з розкриттям в ній філософської глибини змісту, вічних життєвих тем. Розглядаючи основне коло піаністичних завдань, необхідно акцентувати важливість виконавського аналізу, який уможливлює для інтерпретатора самостійні творчі пошуки. Здатність до народження цікавих виконавських рішень передбачає високий рівень культури піаніста, наявність у нього асоціативного мислення, яке створює невидимий підтекстовий фундамент для виконання будь-якої музики.

Виконавець має бути готовим до частих змін образів і настроїв, оскільки творчість Чжан Чжао романтична, багата за образно-емоційним змістом. Потрібно уявити собі різні сюжетні сцени, пов'язуючи їх з різними розділами твору. Яскраві образні характеристики епізодів фантазії допоможуть піаністові правильно налаштуватися і представити необхідні тембри, темпи і настрої. Слухові враження від прослуховування пекінської опери, звучання китайських народних інструментів повинні стати основою реалізації об'єктивних властивостей фортепіанної фактури, відтворення на фортепіано закладених у нотному запису твору особливостей ритміки, динаміки, агогіки, тембрових і регістрових барв, ладового колориту. Змістовність фактури проявляється у взаємодії різноманітних компонентів, характерних саме для даного твору. В результаті народжується образ, наповнений змістом, насичений емоційним звучанням. Таким чином, музичний зміст залежить не тільки від основної мелодико-гармонічної ідеї, але й від iii фактурного втілення. Фактура фантазії багатопланова, і це вимагає від виконавця високої звукової майстерності у відтворенні колориту, озвучуванні різноманіття мелодичних ліній і підголосків.

Важливо, щоби виконавець чітко розумів завдання, що стоять перед ним. Одна $з$ важливіших установок - ретельно проаналізованими, вивіреними засобами піаніст має донести до слухача всю складну форму в цілому, жоден елемент не повинен закрити перспективи образу; при всьому розмаїтті епізодів твір має бути об'єднаний, справляти цілісне враження. Окрім того, у творі Чжан Чжао дуже точно 
позначені динаміка й агогіка. Однак навіть найточніший нотний запис не може вмістити все образно-емоційне багатство музики. I, оскільки на папері фіксується тільки текст, а підтекст його слід розкрити інтерпретаторові, останній отримує можливість творчого співавторства 3 композитором в прочитанні і виконанні твору. Необхідно відзначити, що різні виконавці можуть демонструвати істотно різне розуміння одного і того ж твору, внаслідок чого іноді доводиться говорити про відмінності в самому змісті твору, що звучить.

«Піхуан» привертає увагу виконавців радісним, піднесеним настроєм, підвищеним життєвим тонусом, оригінальністю художньої мови, специфічністю ритму, імпровізаційністю. Твір відображає високі досягнення китайської піаністичної школи, значення якої вже давно вийшло за межі національних кордонів, посідаючи в справі виховання молодих виконавців одне з найпочесніших місць.

Вивчення виконавської інтерпретації фортепіанних творів Чжан Чжао, виявлення взаємозв'язків між виразовими засобами та особливостями авторського стилю має багатостороннє значення. На основі аналізу інтерпретації фортепіанної фантазії «Піхуан» видатним китайський піаністом Юнді Лі та перевірки висновків теоретичного розгляду практикою концертних виступів, ми маємо можливість встановити певні зв'язки в фортепіанній творчості Чжан Чжао, які простежуються як стійкі ознаки його стилю.

\section{ЛІТЕРАТУРА}

Дятлов, Д. А. (2013). Исполнительский анализ пианиста как основа интерпретации. Известия Самарского научного ичентра Российской академии наук, т. 15, 2(3), 804-806.

Чень, Жуньсюань. (2014). Импрессионизм в фортепианной музыке китайских композиторов. (Дис. ...канд. искусствоведения). Харьковский национальный университет искусств имени И. П. Котляревского. Харьков, 262.

Чжан, Гуанцзянь. (2019). Композитор Чжан Чжао: взгляд на развитие современной китайской фортепианной музыки. Проблеми взаємодї̈ мистецฺтва, педагогіки та теорії і практики освіти, 52, 85-100.

Lock, Lourens (2003, July 14). Interview mit dem Pianisten Lee Yundi. Der Musikmarkt (Starnberg), S. 6. GmbH \& Со [нім.]. 
叶红. (2015). 铜琴中的粉墨人生. 张朝钢琴作品《皮黄》. 戏曲元素分析 年 第十二期《音乐创作》第12年116-118月 [Йи, Хонг. (2015). Відображення чунциньського життя. Аналіз елементів опери в фортепіанному творі Чжан Чжао «Піхуан». Створення музики, 12, 116-118] [кит.].

张宏伟. (2016). 《熔古铸今、中西合璧》。和声研究第2.年33-36月.

[Чжан, Хунвей. (2016). Злиття древнього та сучасного, поєднання китайського та західного в «Китайській мрії» Чжан Чжао. Науково-дослідницький інститут гармонії, 2, 33-36] [кит.].

段微. (2016). 《镇南山谣三首》创作中的文化体现与创新发展. 北华大学学 报《社会科学版》. 第17卷第3期 133-136月 [Дуань, Вей. (2016). Культурне втілення та творчий розвиток в творі «Три народні пісні з селищ в горах Наньшань». Журнал університету Бейхуа «Суспільні науки», 17, 3, Jun., 133-136] [кит.].

聂莹. (2015). 谱写中国《钢琴梦》, 铸就东方文明的朝圣之路. 访中国著名 作曲家张朝 年第三期 音乐创作第3期。第32-34页。 [Hі Ін. (2015). Створення «Китайської мрії» для фортепіано. На шляху до затвердження ролі Східної цивілізації. Інтерв'ю з Чжан Чжао, відомим китайським композитором. Музика, 3, 32-34] [кит.].

住锦兰. (2006). 成长的感悟. 青年作曲家张朝的. 变奏曲. 中央民族大学学

报 (学社会科学版) 第4期 第 33 卷. [Цзін, Цзінлан. (2006). Відчуття росту. Варіації молодого композитора Чжан Чжао. Журнал Центрального університету в справах національностей («Філософія і суспільні науки»), 4, 33. Пекін] [кит.].

齐晶. (2015). 也谈张朝钢琴曲《皮黄》的创作特色 基于对作品中京剧音乐 元素的分析. 湖州师范学院学报. 第37卷第9期 2015年9月. [Ці, Цзін. (2015). Розгляд творчих особливостей фортепіанної п'єси Чжан Чжао «Піхуан» на основі аналізу музичних елементів пекінських опер. Журнал педагогічного коледжу Хучжоу, 37, 9] [кит.].

\section{REFERENCES}

Chen, Zhunsyuan. (2014). Impressionizm v fortepiannoy muzyke kitayskikh kompozitorov [Impressionism in the piano music of Chinese composers]. (PhD Dissertation). Kharkov National University of Arts named after I. P. Kotlyarevsky. Kharkov, 262 [in Russian]. 
Duàn, Wēi. (2016). 《Zhèn Nánshān yáo sān shǒu》 chuàng zuò zhōng de wén huà tǐ xiàn yŭ chuàng xīn fā zhăn. Běihuá dà xué xué bào (shè huì kē xué băn). Dì 17 juăn dì 3 qī 133-136 yuè [Duan, Wei. (2016). Cultural embodiment and creative development in the work "Three folk songs from villages in the mountains of Nanshan”. Beihua University Journal, Social Sciences, 17, 3, Jun., 133-136] [in Chinese].

Dyatlov, D. A. (2013). Ispolnitelskiy analiz pianista kak osnova interpretatsii [The pianist's performing analysis as a basis for interpretation]. Izvestiya Samarskogo nauchnogo tsentra Rossiyskoy akademii nauk [The News of the Samara Scientific Center of the Russian Academy of Sciences], vol. 15, 2(3), 804-806 [in Russian].

Lock, Lourens (2003, July 14). Interview mit dem Pianisten Lee Yundi [Interview with the pianist Lee Yundi]. Der Musikmarkt (Starnberg) [The music market (Starnberg)]. P. 6. GmbH \& Co [in German].

Niè, Yíng. (2015). Pǔ xiě zhōng guó 《Gāng qín mèng》, Zhù jiù dōng fāng wén míng de cháo shèng zhī lù. Făng zhōng guó zhe míng zuò qū jiā Zhāng Cháo nián dì sān qī yīn lè chuàng zuò dì3qīo dì 32-34 yè [Ni, In. (2015). Creating a "Chinese dream" for piano. On the way to asserting the role of Eastern civilization. Interview with Zhang Zhao, a famous Chinese composer. Music, 3, 32-34] [in Chinese].

Qí, Jīng. (2015). Yě tán Zhāng Cháo gāng qín qū 《Píhuáng》 de chuàng zuò tè sè jī yú duì zuò pǐn zhōng jīng jù yīn lè yuán sù de fēn xī. Húzhōu shī fàn xué yuàn xué bào. Dì 37 juăn dì 9qī 2015 nián 9 yuè [Qi, Jing. (2015). Consideration of the creative features of Zhang Zhao's piano piece "Pihuang" based on the analysis of the musical elements of Beijing operas. Journal of Huzhou Pedagogical College, 37, 9] [in Chinese].

Yè, Hóng. (2015). Tóng qín zhōng de fěn mò rén shēng. Zhāng Cháo gāng qín zuò pǐn 《Píhuáng》. Xì qū yuán sù fên xī nián dì shí èr qī 《Yìn lè chuàng zuò》, dì 12 nián 116-118 yuè [Yi, Hong. (2015). Reflection of Chongqing life. Analysis of the elements of opera in the piano work of Zhang Zhao "Pihuang". Music Creation, 12, 116-118] [in Chinese].

Zhang, Guangjian. (2019). Kompozitor Chzhan Chzhao: vzglyad na razvitiye sovremennoy kitayskoy fortepiannoy muzyki [Composer Zhang Zhao: a look at the development of contemporary Chinese piano music]. Problemy vzayemodii mystetstva, pedahohiky ta teorii i praktyky osvity [Problems of Interaction of Art, Pedagogy, Theory and Practice of Education], 52, 85-100 [in Russian] 
Zhāng, Hóngwěi. (2016). 《Róng gǔ zhù jīn、 zhōng xī hé bì 》. Hé shēng yán gul̆ dì 2. Nián 33-36 yuè [Zhang, Hongwei. (2016). A fusion of ancient and modern, a combination of Chinese and Western in the "Chinese Dream" by Zhang Zhao. Harmony Research Institute, 2, 33-36] [in Chinese].

Zhuī, Jǔnlán. (2006). Chéng zhăng de găn wù. Qīng nián zuò qū jiā Zhāng Cháo de. Biàn zòu qū. zhōng yāng mín zú dà xué xué bào (xué shè huì kē xué băn), dì 4 qī dì 33 juăn [Jing, Jinglan. (2006). Feeling of growth. Variations by the young composer Zhang Zhao. Journal of the Central University for Nationalities ("Philosophy and Social Sciences"), 4, 33. Beijing] [in Chinese].

Стаття надійшла до редакиї 12.02.2020 р. 